\title{
ANALISIS FAKTOR-FAKTOR YANG MEMPENGARUHI STRUKTUR MODAL PADA CV BENGKEL BUNGA HARAPAN DI KABUPATEN BERAU
}

\author{
Oleh Sayugo Adi Purwanto, Karmila Sulistiani \\ Sekolah Tinggi Ilmu Ekonomi Muhammadiyah Tanjung Redeb
}

\begin{abstract}
Determination of capital structure is very important for companies and parties outside the company such as creditors and investors because it is very basic and has a long-term impact. One important consideration that must be considered carefully before determining the company's capital structure is the consideration of the amount of capital costs from all funds / capital used by the company. In determining the capital structure must be able to reflect the balance or comparison between foreign capital and own capital that is best in a company influenced by many factors, including: asset structure and earning stability.

CV Bunga Harapan Workshop in Berau District in the face of tight business competition must be able to establish an optimal capital structure. This is because the capital structure is an important problem for every company, because the good and bad capital structure will have a direct effect on the company's financial position. The initial observation shows CV Bunga Harapan Workshop in Berau District does not understand the problem of the capital structure. The purpose of this study was to determine the effect of asset structure and earnings stability on the capital structure on CV Harapan Bunga Workshop in Berau District. Data analysis tools used were normality test, multicollinearity test, autocorrelation test, multiple linear regression analysis, determination coefficient, $\mathrm{t}$ test and $\mathrm{F}$ test.

The results of this study conclude that the structure of assets and earnings stability have a significant effect on the capital structure of CV Bunga Harapan Workshop in Berau District. This is evidenced by the results of the F test where F-count is greater than F-table $(21.115>4.74)$ and significant value $0.001<0.05$. The asset structure has a significant effect on the capital structure at CV Bunga Harapan Workshop in Berau District. This is evidenced by the results of the $t$ test where $-t$ count is smaller than -t-table $(-3,078<-2,365)$ and significant value $(0,000)$ smaller than 0,05. Earning stability has a significant effect on the capital structure at CV Bunga Harapan Workshop in Berau District. This is evidenced by the results of the t test where $t$-count is greater than t-table (2.975> 2.365) and a significant value (0.021) which is smaller than 0.05.
\end{abstract}

Kata Kunci: Struktur Modal, Struktur Aktiva, Stabilitas Earning.

\section{PENDAHULUAN}

Suatu perusahaan dinilai berkem-bang atau tidaknya terutama dapat diketahui melalui perkembangan kondisi keuangannya.Perusahaanjuga meng-hadapimasalah seperti produksi, pemasaran dan personalia, yang merupakan masalah sentral dalam perusahaan untuk mencapai tujuan yang diinginkan. Perkembangan kondisi keuangan perusahaan menyangkut masalah fungsi keuangan yang dimiliki oleh perusahaan yang bersangkutan.

Fungsi keuangan tidak dapat dipisahkan dengan fungsi-fungsi lainnya dalam perusahaan. Hambatan terhadap produksi akan berpengaruh terhadap pemasaran hasil produksi. Kurangnya dana misalnya dapat menghambat kegiatan produksi perusahaan sehingga masalah keuangan sangat erat hubungan-nya dengan masalah produksi, pembelian, penjualan dan masalah-masalah lain yang penting dalam perusahaan.

Pada waktu yang lalu financial officer hanya berurusan dengan masalah besarnya dana yang diperlukan oleh perusahaan dan bertanggung jawab untuk mendapatkan dana tersebut. Pada sistem yang baru financial manager diharapkan mampu mengelola persoalan-persoalan fundamental mengenai operasi perusahaan seperti beberapa besar 
dana perusahaan yang seharusnya ada dan berapa besar kecepatan pertumbuhannya, dalam bentuk apa aktiva harus dipertahankan oleh perusahaan dan bagaimana komposisi hutang yang selanjutnya.

Keuangan merupakan fungsi dari suatu perusahaan yang memperhatikan aliran uang/modal, dari dalam perusa-haan (intern) dan dari luar perusahaan (ekstern) ke dalam perusahaan. Modal yang berasal dari dalam perusahaan (intern) biasanya terbatas. Oleh karena itu pihak manajemen berupaya memperoleh tambahan dana yang berasal dari luar perusahaan (ekstern) dengan meminjam kepada kreditur atau melalui pemodalan dalam bentuk hutang (debt financing).

Pemenuhan kebutuhan modal tidak terlepas dari risiko finansial. Risiko tidak bisa membayar kembali hutang dan kewajiban-kewajiban finansial yang lain. Sebagai akibat atas naiknya bagian dari hutang atau saham preferen di dalam struktur modal, maka beban-beban tetap bagi perusahaan juga akan naik dengan kenaikan beban-beban finansial. Apabila hal ini terjadi maka dapat menyebabkan kebangkrutan.

Penetapan struktur modal sangat penting bagi perusahaan dan pihak-pihak di luar perusahaan seperti kreditur dan investor karena sangat mendasar dan berdampak jangka panjang. Perusahaan yang agresif selalu berusaha mencari pinjaman sebanyak mungkin, tanpa menghiraukan dampak buruk yang akan terjadi di masa yang akan datang. Sedangkan bagi perusahaan yang konservatif selalu menjaga rasio hutang dan equity pada kondisi yang aman.

Struktur modal dapat dipandang dari dua sudut, yaitu dari sudut pemberi pinjaman (kreditur) dan dari sudut perusahaan sebagai penerima pinjaman (debitur). Bagi kreditur, risiko dikaitkan dengan kemungkinan perusahaan tidak mampu membayar kembali bunga dan pokok pinjamannya sesuai dengan yang dijadwalkan. Bagi perusahaan, risiko dalam konteks struktur modal adalah kemungkinan terjadinya sesuatu yang dapat berakibat buruk terhadap kinerja perusahaan.

Salah satu pertimbangan penting yang harus diperhatikan secara cermat sebelum menentukan struktur modal perusahaan ialah pertimbangan besarnya biaya modal dari seluruh dana/modal yangdipergunakanperusahaan. Besarnya tingkat biaya modal akan menentukan kelanjutan dan pertum-buhan usaha di masa mendatang.

CV Bengkel Bunga Harapan di Kabupaten Berau dalam menghadapi ketatnya persaingan bisnis harus mampu menetapkan struktur modal optimal. Hal itu disebabkan karena sebagaimana telah diuraikan di atas struktur modal merupakan masalah penting bagi setiap perusahaan, karena baik buruknya struktur modal akan mempunyai efek yang langsung terhadap posisi finansial perusahaan.

Pengamatan awal yang dilakukan penulis pada CV Bengkel Bunga Harapan menunjukkan perusahaan ini belum memahami mengenai permasa-lahan struktur modal tersebut. Hal ini disebabkan karena pimpinan perusahaan dalam menjalankan aktivitas operasional perusahaannya masih bersifat sederhana atau secara tradisional, dimana belum menerapkan fungsi-fungsi manajemen yang salah satunya adalah fungsi keuangan perusahaan. Hal ini memungkinkan timbulnya permasalahan keuangan di masa mendatang apabila ingin berkembang lebih besar.

Dari fenomena tersebut kiranya perlu dilakukan analisis tentang faktor-faktor yang mempengaruhi manajemen perusahaan dalam menentukan struktur modalnya. Dalam penetapan struktur modal harus mampu mencerminkan perimbangan atau perbandingan antara modal asing dengan modal sendiri yang terbaik pada suatu perusahaan yang dipengaruhi oleh banyak faktor, dimana faktorfaktor utama yang mempengaruhi struktur modal diantaranya: tingkat bunga, struktur aktiva, stabilitas earning, kadar risiko dari aktiva, besarnya jumlah modal yang dibutuhkan, keadaan pasar modal, sifat manajemen dan besar kecilnya suatu perusahaan.

Pentingnya penetapan struktur modal bagi kelangsungan perusahaan mendorong, penulis untuk melakukan penelitian terhadap faktor-faktor yang mempengaruhi struktur modal pada CV Bengkel Bunga Harapan. Dimana dalam penelitian ini penulis memfokuskan pada faktor struktur aktiva dan faktor stabilitas earning. Hal tersebut dikarenakan hanya kedua faktor tersebut yang memungkin-kan untuk dilakukan perhitungan indikatornya dengan mempertimbangan kondisi pada CV Bengkel Bunga Harapan yang memiliki keterbatasan datakeuangannya.

\section{METODE PENELITIAN Definisi Operasional}

Definisi operasional dimaksudkan untuk memberikan penjelasan terhadap indikator-indikator yang akan diteliti sebagaimana judul dalam penelitian, yaitu: 
1. Struktur modal sebagai variabel terikat $(\mathrm{Y})$ dalam penelitian ini adalah perbandingan antara hutang jangka panjang dengan modal sendiri pada CV Bengkel Bunga Harapan di Kabupaten Berau, diukur dalam satuan rupiah.

2. Struktur aktiva sebagai variabel bebas (X1) dalam penelitian ini adalah perbandingan antara aktiva lancar dengan aktiva tetap yang dimiliki oleh CV Bengkel Bunga Harapan di Kabupaten Berau, diukur dalam satuan rupiah.

3. Stabilitas Earning sebagai variabel bebas (X2) dalam penelitian ini adalah perkembangan earning yang diperoleh $\mathrm{CV}$ Bengkel Bunga Harapan di Kabupaten Berau, diukur dalam satuan rupiah.

\section{Unit Analisis, Populasi dan Sampel}

Unit analisis dalam penelitian ini adalah CV Bengkel Bunga Harapan di Kabupaten Berau. Populasi dalam penelitian ini adalah seluruh laporan keuangan pada CV Bengkel Bunga Harapan di Kabupaten Berau sejak berdirinya perusahaan ini hingga Tahun 2017. Sampel yang digunakan dalam penelitian ini adalah laporan keuangan CV Bengkel Bunga Harapan di Kabupaten Berau Tahun 2008 sampai dengan Tahun 2017.

Metode pengambilan sampel yang digunakan nonprobability sampling dengan teknik purposive sampling.

\section{Jenis dan Sumber Data} yaitu:

Jenis data yang digunakan dalam penelitian ini,

1. Data kualitatif, berupa data yang bukan berupa angka-angka, seperti gambaran umum CV Bengkel Bunga Harapan di Kabupaten Berau, struktur organisasi dan data lain yang diperlukan.

2. Data kuantitatif, berupa angka-angka yang dapat dihitung seperti neraca dan laporan laba rugi CV Bengkel Bunga Harapan di Kabupaten Berau serta data lainnya yang dapat mendukunganalisis\& pembahasan.

Sumber data dalam penelitian yaitu:

1. Data primer, dengan mengadakan pengamatan serta wawancara secara langsung dengan pimpinan dan karyawan yang ada kaitannya dengan masalah yang dibahas.

2. Data sekunder, dengan mengumpul-kan dokumen-dokumen serta sumber-sumber lainnya yang telah diolah oleh pihak lain selain peneliti, berupa laporan keuangan pada CV Bengkel Bunga Harapan di Kabupaten Berau.

\section{Metode Pengumpulan Data}

Pengumpulan data menggunakan:dokumentasi dan studi kepustakaan.

\section{Alat Analisis}

Analisis data dilakukan dengan bantuan program Statistical Package for Social Science (SPSS). Alat analisis yang digunakan yaitu:

1. Uji Normalitas

2. Uji Multikolinearitas

3. Uji Autokorelasi

4. Analisis Regresi Linier Berganda

5. Koefisien Determinasi (R Square)

6. Uji t

7. Uji F.

\section{ANALISIS DAN PEMBAHASAN} ANALISIS

\section{Uji Normalitas}

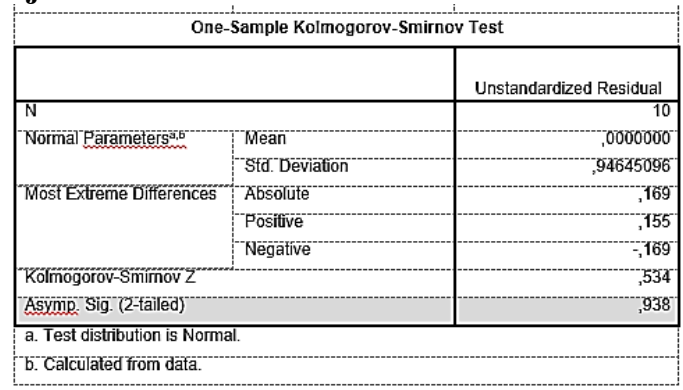

Hasil pengujian normalitas data penelitian dengan menggunakan program SPSS, berikut langkah-langkah pengujiannya:

a. Analisis:

Ho : Populasi berdistribusi normal

Ha : Populasi tidak berdistribusi normal

b. Dasar pengambilan keputusan adalah berdasarkan probabilitas:

1) Jika nilai probabilitas/Asymp. Sig (2-tailed) $>0,05$ maka Ho diterima.

2) Jika nilai probabilitas/Asymp. Sig (2-tailed) $\leq 0,05$ maka Ho ditolak.

c. Keputusan:

$0,938>0,05$ maka Ho diterima, yang berarti populasi berdistribusi normal.

Dapat disimpulkan bahwa semua data dalam penelitian ini memenuhi kriteria uji normalitas, dimana semua data berdistribusi normal. 


\section{a. Uji Normalitas}

\begin{tabular}{|c|c|c|c|c|c|}
\hline \multicolumn{6}{|c|}{ Coefficients $^{2}$} \\
\hline & & \multicolumn{2}{|c|}{$\begin{array}{l}\text { Unstandardized } \\
\text { Coefficients }\end{array}$} & \multicolumn{2}{|c|}{ Collinearity Statistics } \\
\hline \multicolumn{2}{|c|}{ Model } & $\mathrm{B}$ & Std. Error & Tolerance & VIF \\
\hline 1 & (Constant) & 5,446 &, 796 & & \\
\hline & Struktur Aktiva & -.035 & .006 & 980 & 1,021 \\
\hline & Pertumbuhan Earning & .243 & .082 & 980 & 1,021 \\
\hline
\end{tabular}

Hasil pengujian multikolinearitas data penelitian dengan menggunakan program SPSS dapat diketahui bahwa nilai VIF dari masing-masing variabel bebas, yaitu struktur aktiva dan stabilitas earning $=1,021<10$, maka dapat disimpulkan bahwa tidak terjadi adanya multikolinearitas.

\section{Uji Autokorelasi}

\begin{tabular}{|l|c|r|r|r|r|}
\hline Model Summary & \\
\hline Model & $\mathrm{R}$ & R Square & $\begin{array}{c}\text { Adjusted R } \\
\text { Square }\end{array}$ & $\begin{array}{c}\text { Std. Error of the } \\
\text { Estimate }\end{array}$ & Durbin-Watson \\
\hline 1 &, $926^{3}$ &, 858 &, 817 & 1,073 & 1,849 \\
\hline
\end{tabular}

Hasil pengujian autokorelasi data penelitian dengan meng-gunakan program SPSS dapat dilihat pada Lampiran 2. Berdasarkan hasil tersebut dengan menggunakan uji regresi linear berganda dengan 2 variabel bebas dan 1 variabel terikat $(\mathrm{k}=3)$ serta jumlah sampel sebanyak $10 \quad(\mathrm{~T}=10)$, maka didapatkan hasil Durbin Watson-hitung $(\mathrm{d})=1,849$ dan nilai $(4-\mathrm{d})=2,151$. Selanjutnya dicari nilai $\mathrm{dL}$ dan dU pada $\mathrm{T}=10$ dan $\mathrm{k}=3$ pada tabel Durbin Watson, maka diketahui nilai $\mathrm{dL}=0,69715$ dan $\mathrm{dU}$ $=1,64134$.

Berdasarkan kriteria pengujian autokorelasi di atas dapat diketahui:

a. $\mathrm{d}>\mathrm{dU}$ atau $1,849>1,64134$, maka tidak terdapat autokorelasi positif.

b. $(4-$ d) $>$ dU atau $2,151>1,64134$, maka tidak terdapat autokorelasi negatif.

Maka dapat disimpulkan tidak terdapat autokorelasi positif dan tidak terdapat autokorelasi negatif sehingga dapat disimpulkan sama sekali tidak terdapat autokorelasi.

\section{Analisis Regresi Linier Berganda}

\begin{tabular}{|c|c|c|c|c|c|c|}
\hline \multicolumn{7}{|c|}{ Coefficients $^{\mathrm{a}}$} \\
\hline \multirow[b]{2}{*}{ Model } & & \multicolumn{2}{|c|}{ Unstandardized Coefficients } & \multirow{2}{*}{$\begin{array}{c}\begin{array}{c}\text { Standardized } \\
\text { Coefficients }\end{array} \\
\text { Beta }\end{array}$} & \multirow[b]{2}{*}{$t$} & \multirow[b]{2}{*}{ Sig. } \\
\hline & & $B$ & Std. Error & & & \\
\hline \multirow[t]{3}{*}{1} & (Constant) & 5,446 &, 796 & & 6,839 & , 000 \\
\hline & Struktur Aktiva &,- 035 &, 006 &,- 885 & $-6,143$ &, 000 \\
\hline & Pertumbuhan Earning & ,243 &, 082 & ,428 & 2,975 & ,021 \\
\hline
\end{tabular}

Berdasarkan tabel di atas, maka dapat dibuat dalam bentuk persamaan regresi berikut ini:

$\mathrm{Y}=5,446-0,035 \mathrm{X}_{1}+0,243 \mathrm{X}_{2}$

Dari persamaan regresi linier berganda di atas maka dapat diinterpretasikan sebagai berikut:

1. Nilai konstanta adalah 5,446, berarti bahwa dalam keadaan konstan atau tidak ada pengaruh dari struktur aktiva dan stabilitas earning maka struktur modal akan bergerak naik sebesar 5,446 persen.

2. Koefisien regresi struktur aktiva bertanda negatif dengan nilai sebesar 0,035 . Hal ini menunjukkan bahwa struktur aktiva berpengaruh negatif dan tidak searah terhadap struktur modal. Apabila struktur aktiva meningkat sebesar 1 persen, maka struktur modal pada CV BengkelBunga Harapan akan menurun sebesar 0,035 persen dengan asumsi nilai stabilitas earning tetap, begitupun sebaliknya.

3. Koefisien regresi stabilitas earning bertanda positif dengan nilai sebesar 0,243. Hal ini menunjukkan bahwa stabilitas earning berpengaruh positif dan searah terhadap struktur modal. Apabila stabilitas earning meningkat sebesar 1 persen, maka struktur modal pada CV BengkelBunga Harapan juga akan meningkat sebesar 0,243 persen dengan asumsi nilai struktur aktiva tetap, begitupun sebaliknya.

\section{Koefisien Determinasi (R Square)}

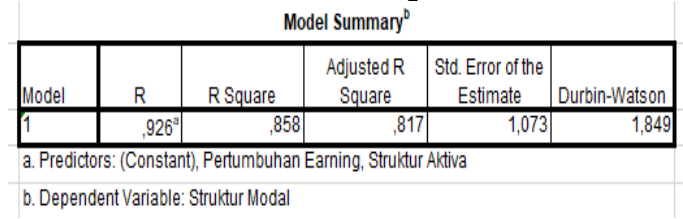

Berdasarkan hasil pengujian pada tabeldi atas, dapat diketahui bahwa nilai R Square adalah 0,858, artinya secara bersama-sama variabel struktur aktiva dan stabilitas earning memberikan variasi penjelasan pada variabel struktur modal CV BengkelBunga Harapan sebesar 85,8 persen. Sedangkan sisanya sebesar 14,2 persen dijelaskan oleh variabel lain yang tidak dimasukkan dalam estimasi model atau berada dalam disturbance error term.

Uji t

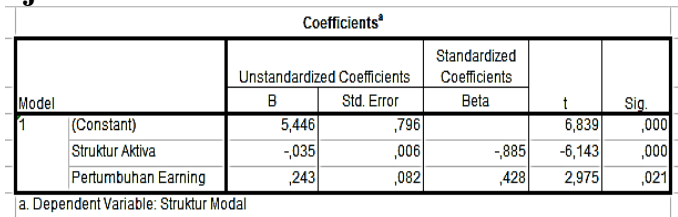


Berdasarkan hasil pengujian pada tabel di atas, dapat diketahui bahwa:

1. Pengaruh struktur aktiva terhadap struktur modal Nilai t-hitung $=-6,143$ dan nilai $\mathrm{t}$-tabel $=2,365$ $(\alpha=5 \%$; df $=10-1-2=7)$. Dapat ditentukan -thitung $<\mathrm{t}$-tabel atau $-6,143<-2,365$, artinya strukturaktivaberpengaruh signifi-kan terhadap struktur modal CV BengkelBunga Harapan.

2. Pengaruh stabilitas earning terhadap struktur modal

Nilai t-hitung $=2,975$ dan nilai t-tabel $=2,365(\alpha$ $=5 \% ; \mathrm{df}=10-1-2=7)$. Dengan demikian dapat ditentukan: t-hitung > t-tabel atau 2,975 > 2,365, maka artinya stabilitas earning berpengaruh signifikan terhadap struktur modal pada CV BengkelBunga Harapan.

Uji F

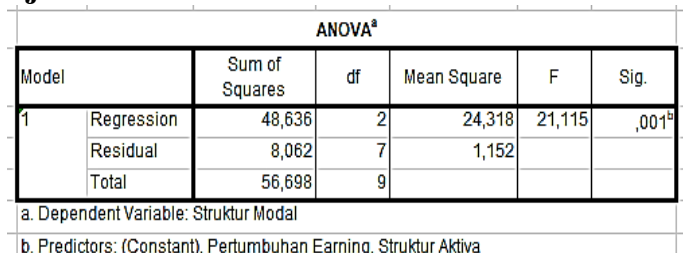

Berdasarkan hasil pengujian pada tabel tersebut, maka dapat diketahui nilai $\mathrm{F}$-hitung = 21,115 sementara F-tabel $=4,74($ dimana $\alpha=5 \%$; $\mathrm{df}_{1}=3-1=2$ dan $\mathrm{df}_{2}=10-3=7$ ). Maka dapat ditentukan bahwa F-hitung > F-tabel atau 21,115 > 4,74. Dengan demikian disimpulkan menerima Ho, yang artinya secara bersama-sama struktur aktiva dan stabilitas earning berpengaruh signifikan terhadap struktur modal pada CV BengkelBunga Harapan.

\section{PEMBAHASAN}

\section{Pengaruh Struktur Aktiva Terhadap Struktur Modal}

Koefisien regresi struktur aktiva bernilai 0,035 dan bertanda negatif. Tanda negatif ini memiliki arti bahwa antara struktur aktiva dan struktur modal memiliki hubungan yang tidak searah. Hubungan yang tidak searah ini menggambarkan bahwa kenaikan pada nilai struktur aktiva akan memberikan dampak negatif yang mengakibatkan penurunan struktur modal pada CV Bengkel Bunga Harapan.

Hasil uji t terdapat nilai signifikan struktur aktiva sebesar 0,000 , dimana nilai signifikan ini lebih kecil dari nilai probabilitas $(0,05)$. Nilai thitung yang didapat 6,143 dan bernilai negatif sedangkan nilai t-tabel 2,365. Nilai -t-hitung yang lebih kecil dari nilai -t-tabel dan nilai signifikan yang lebih kecil dari 0,05 menunjukkan struktur aktiva secara parsial memiliki pengaruh signifikan terhadap struktur modal pada CV Bengkel Bunga Harapan.

Pengaruh yang signifikan meng-gambarkan CV Bengkel Bunga Harapan banyak memanfaatkan aktiva tetapnya sebagai jaminan dalam memperoleh hutang. Dengan demikian maka CV Bengkel Bunga Harapan dengan aktiva tetap yang tinggi memiliki kesempatan besar dalam mendapatkan hutang jangka panjang. Sesuai teori struktur modal yaitu trade off theory yang intinya menyatakan bahwa perusahaan harus menyeimbangkan antara manfaat menggunakan hutang dan biaya yang ditimbulkan dari penggunaan hutang untuk mencapai struktur modal yang optimal.

\section{Pengaruh Stabilitas Earning Terhadap Struktur Modal}

Koefisien regresi stabilitas earning bernilai 0,243 dan bertanda positif. Tanda positif memiliki arti bahwa antara stabilitas earning dan struktur modal memiliki hubungan searah. Hubungan searah ini berarti bahwa kenaikan stabilitas earning yang diperoleh CV Bengkel Bunga Harapan memberikan dampak positif terhadap kenaikan struktur modalnya.

Hasil uji t terdapat nilai signifikan stabilitas earning sebesar 0,021 , nilai signifikan ini lebih kecil dari nilai probabilitas $(0,05)$. Nilai t-hitung yang didapatkan 2,975 dan bernilai positif, sedangkan nilai t-tabel 2,365. Nilai t-hitung yang lebih besar dari nilai t-tabel dan nilai signifikan yang lebih kecil dari 0,05 menunjukkan bahwa stabilitas earning secara parsial memiliki pengaruh signifikan terhadap struktur modal pada CV Bengkel Bunga Harapan.

Tingkat stabilitas earning (laba) yang tinggi mendorong CV Bengkel Bunga Harapan untuk lebih banyak menggunakan dana internal dalam struktur modalnya. Semakin besar laba yang diperoleh maka diharapkan semakin besar pula dana tersedia untuk operasional perusahaan. Pernyataan ini sesuai dengan pecking order theory yang menyatakan bahwa perusahaan yang memiiki profitabilitas yang tinggi akan menggunakan dana pinjaman yang sedikit, karena kebutuhan dana sudah tercukupi dari penggunaan sumber dana internal yaitu laba yang ditahan. Pengaruh yang signifikan dalam penelitian ini menunjukkan keadaan yang kondusif bagi usaha CV Bengkel Bunga Harapan dalam memperoleh tingkat stabilitas laba yang tinggi. 


\section{Pengaruh Struktur Aktiva dan Stabilitas Earning}

Berdasarkan uji $\mathrm{F}$ terdapat nilai signifikan struktur aktiva dan stabilitas earning sebesar 0,001 dimana nilai signifikan ini lebih kecil dari nilai probabilitas $(0,05)$. Nilai F-hitung yang didapat sebesar 21,115 dan bernilai positif, sedangkan nilai F-tabel 4,74. Nilai F-hitung yang lebih besar dari nilai F-tabel dan nilai signifikan yang lebih kecil dari 0,05 menunjukkan bahwa struktur aktiva dan stabilitas earning secara simultan memiliki pengaruh yang signifikan terhadap struktur modal pada CV BengkelBunga Harapan.

\section{PENUTUP}

\section{Kesimpulan}

Berdasarkan analisis dan pembahasan yang telah dilakukan, maka dapat disimpulkan beberapa hal, yaitu:

1. Struktur aktiva dan stabilitas earning berpengaruh siginifikan terhadap struktur modal pada CV Bengkel Bunga Harapan di Kabupaten Berau. Hal ini dibuktikan dari hasil uji $\mathrm{F}$ dimana F-hitung yang lebih besar dari F-tabel $(21,115>$ $4,74)$ dan nilai signifikan $0,001<0,05$.

2. Strukturaktivaberpengaruh siginifi-kan terhadap struktur modal pada CV Bengkel Bunga Harapan di Kabupaten Berau. Hal ini dibuktikan dengan hasil uji t dimana -t-hitung yang lebih kecil dari t-tabel $(-6,143<-2,365)$ dan nilai signifikan $(0,000)$ yang lebih kecil dari 0,05 .

3. Stabilitasearning berpengaruh siginifikan terhadap struktur modal pada CV Bengkel Bunga Harapan di Kabupaten Berau. Hal ini dibuktikan dari hasil uji t dimana t-hitung yang lebih besar dari t-tabel $(2,975>2,365)$ dan nilai signifikan $(0,021)$ yang lebih kecil dari 0,05 .

\section{Saran}

Berdasarkan kesimpulan di atas, maka penulis menyampaikan beberapa saran dan masukan, sebagai berikut:

1. Penentuan struktur modal merupakan masalah penting bagi setiap perusahaan karena baik dan buruknya struktur modal akan mempunyai efek langsung terhadap posisi finansial perusahaan. Penulis menyarankan sebaiknya manajemen $\mathrm{CV}$ Bengkel Bunga Harapan perlu memperhatikan faktor-faktor yang mempengaruhi struktur modalnya, khususnya struktur aktiva dan stabilitas earning karena kedua faktor ini terbukti memiliki pengaruh positif dan signifikan terhadap struktur modal CV Bengkel Bunga Harapan.

2. Perimbangan struktur modal perlu dianalisis kembali dengan mempertimbangkan besarnya biaya untuk mendapatkan modal tersebut, yaitu pertimbangan mengenai suku bunga kredit jangka panjang dan besarnya inflasi. Inflasi sangat berpengaruh pada nilai uang yang digunakan dalam operasional perusahaan. Sehingga ketika inflasi tinggi maka penurunan nilai uang juga akan tinggi akibatnya biaya yang dikeluarkan untuk mempertahankan jumlah uang akan tinggi pula. Hal ini menyebabkan biaya modal sendiri juga akan tinggi, maka akan lebih menguntungkan jika perusahaan menggunakan modal yang berasal dari luar perusahaan seperti pinjaman jangka panjang dari bank.

3. Untuk penelitian selanjutnya, apabila ingin melakukan penelitian serupa yaitu mengenai faktor-faktor yang mempengaruhi struktur modal, kiranya dapat menggunakan variabelvariabel lain diluar yang diteliti pada skripsi ini, dengan memperluas atau menggunakan objek penelitian yang belumpernahdigunakan, seperti: analisis rasio profitabilitas, ukuran perusahaan dan pajak.

\section{DAFTAR PUSTAKA}

Amin, Muhammad. 2013. Tafsir Ayat Ekonomi. Sinar Grafika Offset, Jakarta.

Atmaja, Lukas Setia. 2008. Teori dan Praktek Manajemen Keuangan. Penerbit ANDI, Yogyakarta.

Brigham, Eugene F. dan Joel F. Houston. 2013. Dasar-dasar Manajemen Keuangan, Jilid 1 Edisi 11. Salemba Empat, Jakarta.

Departemen Agama RI. 2008. Al-Qur'an dan Terjemahannya: Juz 1-30. PT. Kumudasmoro Grafindo Semarang, Jakarta.

Djarwanto, PS dan Pangestu Subagyo. 2006. Statistik Induktif, BPFE-UGM, Yogyakarta.

Ghozali, Imam. 2013. Analisis Multi-variat dengan Program IBM SPSS 21, Edisi 7. Badan Penerbit Universitas Diponegoro, Semarang.

Hadley, Chris. 2015. Cara Menghitung Rasio Pertumbuhan. https://id.wikihow.com/Menghitung-Rasio-Pertumbuhan. Diakses tanggal 25 Agustus 2018. 
Idri, H. 2016. Ekonomi dalam Perspektif Hadis Nabi. Prenadamedia, Jakarta.

Isnawati. 2015. Analisis Kebutuhan Modal Kerja pada Koperasi Simpan Pinjam Berau Jaya di Tanjung Redeb. Skripsi. Sekolah Tinggi Ilmu Ekonomi Muhammadiyah Tanjung Redeb.

Kasmir. 2010. Pengantar Manajemen Keuangan. Kencana Prenada Media Group, Jakarta.

Munawir. 2016. Analisa Laporan Keuangan, Edisi Keempat. BPFE-UGM, Yogyakarta.

Nita, Noviyanti. 2017. Analisis Faktor-faktor yang Mempengaruhi Struktur Modal Perusahaan Sektor Pertambangan. Jurnal Sosial Humaniora dan Pendidikan Vol.1 No.1, ISSN $2580-5398$.

Priambodo, Taruna Johni. 2014. Pengaruh Struktur Aktiva, Tingkat Pertumbuhan Penjualan dan Profitabilitas Terhadap Struktur Modal (Studi pada perusahaan Tekstil dan Garmen yang listing di BEI periode 2010-2012). Jurnal Administrasi Bisnis (JAB) Vol.9 No.1 April 2014,

Riyanto, Bambang. 2013. Dasar-dasar Pembelanjaan Perusahaan. BPFE-UGM, Yogyakarta.

Santosa, P. B. dan Ashari. 2007. Analisis Statistik dengan Microsoft Excel \&SPSS. Andi, Yogyakarta.

Sartono, R. Agus. 2008. Manajemen Keuangan, Edisi Keempat. BPFE - UGM, Yogyakarta.

Sugiyono. 2013. Metode Penelitian Kuantitatif, Kualitatif dan $R \& D$, Cetakan Ke-19. Alfabeta, Bandung.

Sutrisno. 2007. Manajemen Keuangan, Teori, Konsep dan Aplikasi. EKPNISIA, Fakultas Ekonomi UI, Jakarta.

Suweta, Ni Made Novione Purnama Dewi. 2016. Pengaruh Pertumbuhan Penjualan, Struktur Aktiva dan Pertumbuhan Aktiva Terhadap Struktur Modal. E-Jurnal Manajemen Unud, Vol. 5, No.8, 2016:5172-5199, ISSN: 23028912.

Weston, J. Fred dan Eugene F. Brigham. 2008. Dasar-dasar ManajemenKeuangan, $2^{\text {th }}$ edition. Erlangga, Jakarta.

Wijaya, Tony. 2009. Analisis Data Penelitian Menggunakan SPSS. Universitas Atma Jaya Yogyakarta, Yogyakarta. 